\title{
Verdien av et menneske
}

\author{
Verdier danner et underforstått grunnlag i det personlige møte mellom pasient og lege. At alle mennesker \\ har samme verdi, uavhengig av egenskaper og prestasjoner, er ingen selvfølge. Det kan ikke bevises logisk.
}

Engelsk oversettelse på www.tidsskriftet.no

I FNs menneskerettighetserklæring anses grunnleggende verdier som intuitive og selvinnlysende. Andre betrakter verdier som tillærte og formidlet gjennom kultur og religion (1). I Vesten har den kristne skapelseslæren hatt avgjørende innflytelse på menneskesynet. Den opprinnelige begrunnelse for dette menneskesynet finner vi i Første Mosebok (2).

I en knapp og majestetisk form utmeisles fortellingen om alle tings tilblivelse. Samtidig tegnes et bilde av orden, lovmessighet og en guddommelig hensikt. Skaperakten sluttføres med mennesket og avrundes med at Skaperen selv betrakter sitt verk og konstaterer at alt er overmåte godt. Denne kompakte fortellingen har gjennom årtusener vært et fundament for kristen antropologi, læren om mennesket.

Først fastslås det at mennesket og resten av skaperverket ikke er oppstått ved en tilfeldighet, men ved en villet handling av en guddom. Mennesket er en del av det skapte på linje med alt annet levende, skapt av samme stoff og en del av det store økologiske system. Til denne biologiske kropp ble det lagt en sjelelig og åndelig dimensjon. Den fjerde dimensjonen i den bibelske antropologi er den relasjonelle eller sosiale.

\section{Menneskets verdi}

Mennesket settes i en særstilling i skaperverket og făr en overordnet posisjon. Det skal råde over resten av skaperverket og, enda viktigere, det sies at mennesket skapes i Guds bilde. Det betyr likefrem at mennesket har guddommelige trekk og at Gud har menneskelige trekk. Mennesket har en guddommelig signatur og særstilling som gjør alt menneskeliv hellig og ukrenkelig. Dermed har også alle mennesker lik verdi.

At alle mennesker skulle ha samme verdi, var en ny idé i den første kristne tid. Både det hellenistiske og det romerske riket var klassedelt med nedvurdering av det svake og ufullkomne. Paulus' utsagn i Galaterbrevet om at «her er ikke jøde eller greker, her er ikke slave eller fri, her er ikke mann eller kvinne» (2), var i hans samtid et radikalt utsagn om likestilling. Ved kristningen av Norge tusen år senere var tanken om enkeltmenneskets verdi et brudd med gamle holdninger og normer.

\section{Frihet og fall}

Gud stilte skaperverket til menneskets disposisjon og betrodde mennesket selvsten- dighet og frihet til å gjøre valg i stedet for å være lydige marionetter. Med friheten følger også ansvarlighet. Mennesket er den eneste skapning som holdes ansvarlig for sine handlinger.

Etter den bibelske fortelling lot mennesket seg forføre av Guds motstander. Denne tildragelsen, syndefallet, fremstilles som en arv som senere har heftet ved alle mennesker (2). Mennesker kan derfor ikke klassifiseres som enten onde eller gode. Vi kan kultiveres til hyggelige og samfunnsnyttige personer, men vil alltid beholde en rem av ondskap i sjel og sinn, enten man kaller seg troende eller ikke. Dette samsvarer med all menneskelig erfaring - som Henrik Ibsen skrev: «At leve er krig med trolle / I hjertets og hjernens hvelv.»

\section{Paulinsk antropologi}

Paulus, som var en velutdannet jøde, oppvokst med gresk kultur og språk, skriver innsiktsfullt og selvransakende om menneskenaturen. Om kroppen bruker han to greske begrep: soma og sarx. Menneskets åndelige natur betegnes enten som pneuma eller psyche, og intelligens eller fornuft kalles nous. Nous gjenfinnes i ordet paranoid som da betyr på siden av fornuften. Sarx kan oversettes med kjøtt, men uttrykker også noe mer, nemlig mennesket i dets svakhet. Ifølge Paulus lever ethvert menneske med en indre tvekamp mellom det onde og gode. Selv om mennesker dras mellom det gode og det onde, er deres verdi uforanderlig, på samme måte som en pengeseddel har samme verdi enten den kommer rett fra trykkeriet eller er krøllet og slitt.

\section{Agape}

I klassisk gresk benyttes to begrep for kjærlighet, philos og eros. Philos brukes om vennskap, eros om seksuell kjærlighet. Begge disse springer ut av behov i et subjekt, et jeg. Agape dukker opp som et gresk nyord i Det nye testamente og nevnes $i$ alt 106 ganger i ulike bøyningsformer. Dette springer ut av behov i et objekt, et du. I sin beskrivelse av agape har Paulus det kjente utsagnet: «Så blir de stående, disse tre: tro, håp og kjærlighet. Men størst blant dem er kjærligheten» (2).

Agape er ikke primært knyttet til emosjoner eller sinnsstemning. Den er handlingsorientert, rettet mot andre og har sitt utspring og forbilde i Guds kjærlighet til mennesker.

\section{Praktiserende kjærlighet}

Gjennom Jesu liv og gjerning demonstreres og praktiseres agape. Evangelisten Lukas, som selv var lege i hippokratisk tradisjon, beskriver Jesu emosjonelle reaksjon som splanchniste (norsk: inderlig medfølelse, sterk empati) da han møtte gravfølget etter en enkes eneste sønn (Lukas 10). Det betegner en følelsesmessig reaksjon som tar tak i innvollene.

Et annet grensesprengende element ved Jesu praksis var spørsmålet om hvem som skulle være gjenstand for denne kjærlighet. Hvem angår meg? Jesus besvarer dette spørsmålet med fortellingen om den barmhjertige samaritan. Her utvider han nestebegrepet til å gjelde alle mennesker, uavhengig av alder, kjønn, rase, status og tro.

Historisk har helse og omsorg hatt en sentral plass i kirkens tro og praksis. Bygging av hospital fulgte utbredelsen av kristendommen særlig gjennom etablering av kloster og i de siste århundrer gjennom kristen misjon i Asia og Afrika. Diakoneo er det greske ordet for å tjene, noe som for grekerne var uverdig. Diakoni var en egen, frivillig tjeneste i de urkristne menighetene som besto i utdeling av mat og omsorg for trengende. Rester av dette finnes fortsatt $i$ vårt helsevesen i de private, ideelle institusjonene som kalles diakonale.

\section{Verdier i praksis}

Neppe noen andre yrkesgrupper konfronteres så hyppig med verdimessige problemstillinger som helsearbeidere, og valg av legeyrket er for mange et bevisst verdivalg. Verdier danner et underforstått grunnlag i hvert personlige møte mellom pasient og lege.

\section{Reduksjonisme}

Forskjellige former for reduksjonisme er ofte vanskelig å gjennomskue. Reduksjonismen reduserer menneskets kompleksitet og gjør det mindre enn det er (3).

- Biologisk reduksjonisme: Mennesket reduseres til bare et biologisk vesen, et produkt av fysiologi og kjemi. Du er dine gener. Du er hva du spiser. Dette er skolemedisinens grøft.

- Åndelig reduksjonisme: Mennesket er transcendent. Mennesket er energi og påvirkes av energier. Du kan ta styring over livet ditt ved hjelp av tankene. Dette er grøften for alternativbevegelsen. 


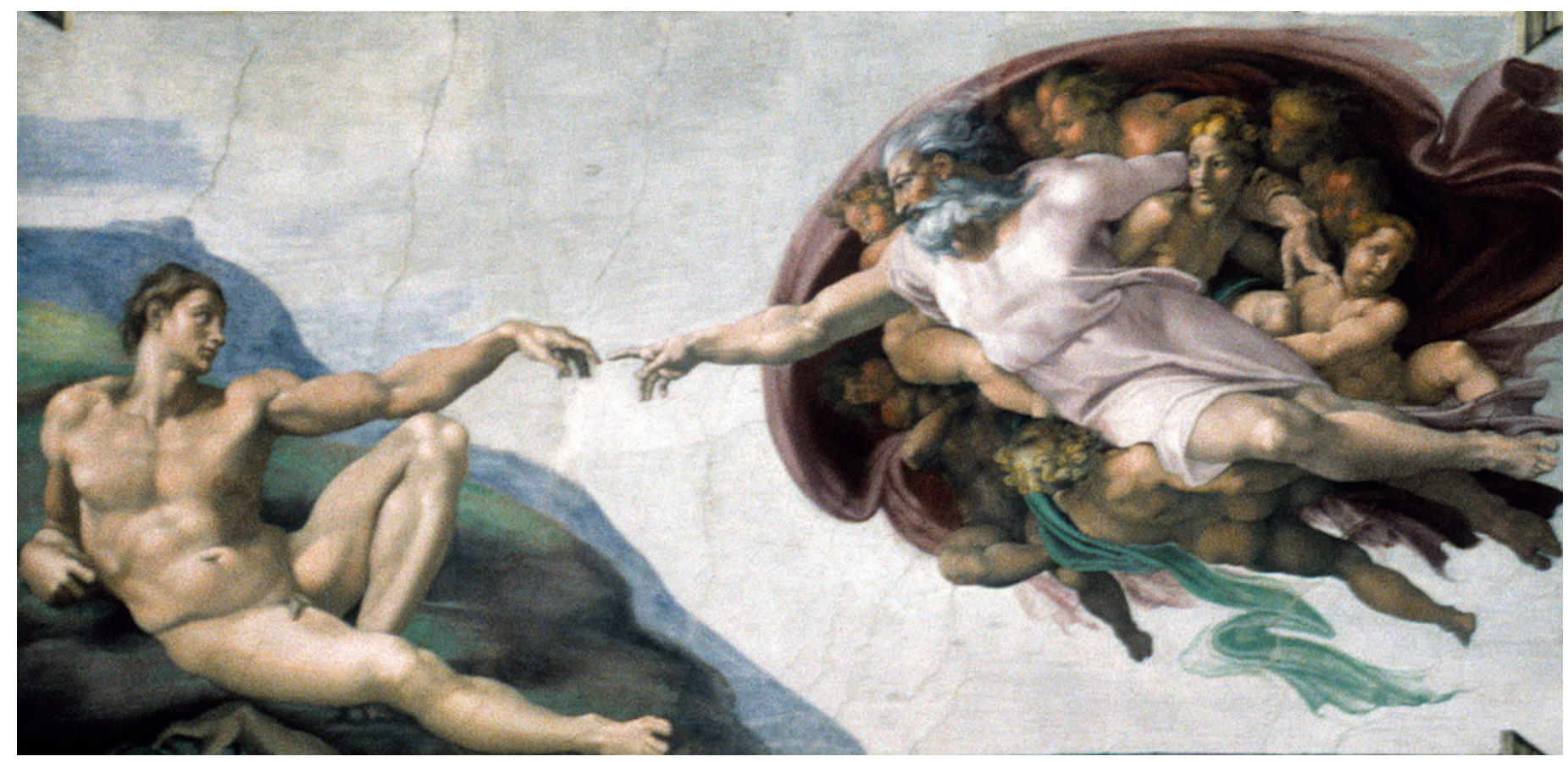

Skapelsen av Adam. Fra taket i Det sixtinske kapell i Vatikanet. Malt av Michelangelo i perioden 1508-12. Foto @ Mikkel Østergaard/Samfoto/Scanpix

- Relasjonell reduksjonisme: Mennesket er uavhengig individualist, ubundet og frigjort, - eller motsatt, bundet av autoriteter eller av massene.

Mot dette må helsearbeidere avvise alle former for reduksjonisme og avbalansere mennesket som en helhet, et biologisk, psykologisk, åndelig og sosialt vesen.

\section{Verdier og valg}

I vårt samfunn er det bred enighet om et likeverdig og tilgjengelig behandlingstilbud uavhengig av penger, status og makt. Det sitter lenger inne å tenke at dette også gjelder globalt.

De siste årene har det trengt seg inn tankegods og terminologi fra produksjonsbedrifter i helsevesenet. Pasientene gjøres til en vare, tjenester konkurranseutsettes, terapier vurderes ut fra kostnader og sykdommers samfunnsøkonomiske byrde beregnes. En slik tenkning kan bidra til et avstumpet menneskesyn og true sentrale verdier (4).

Antikkens leger var herre over både liv og død og ble derfor møtt med mistro (5). Hippokrates, og senere den kristne lære, brøt med dette da det ble satt et skarpt skille: Legens oppgave var å helbrede, lindre og trøste - aldri å ta liv. I dag utfordres idealene om det absolutte menneskeverd i begge ender av livsløpet. Den avgjørende test på menneskeverd er ikke hvor lenge helsevesenet klarer å holde et menneske i live, men med hvilken verdighet hvert menneske behandles.

For vordende leger er en erkjennelse av den menneskelige natur som en arena for kampen mellom ondt og godt en avgjørende innsikt for å forstå seg selv og sine pasienter. Skillet går ikke mellom de gode og aktverdige på den ene siden og de håpløse og ufordragelige på den andre siden. Begge sidene finnes i ethvert menneske.

Når mennesket rammes av ulykke eller sykdom, rammes det både biologisk, psykologisk og relasjonelt. Per Fugelli beskrev egen erfaring med ankelbrudd treffende: «Plutselig ligger du der uten de gjøremål og narrespill som holder det eksistensielle drama borte. Plutselig befinner du deg i et slags sannhetens laboratorium, hvor verdier og livsformer blir satt på prøve. Sykdommen blir som en eksistensiell krystalliseringsprosess hvor flyktighetene, ting og pynt faller av. Tilbake blir tilværelsens kjerner, det du tror på og dem du er glad i» (6).

Helsearbeidere står daglig $\mathrm{i}$ en strøm av mennesker som er rammet på kropp og sjel. Få yrkesgrupper får i samme grad som legen innsyn i livets skyggesider: irrasjonelle handlinger, vold, konflikter, tragedier, selvdestruktiv atferd og løgn. Utdanningen har i liten grad forberedt oss på denne krevende hverdag. Tidspress gir lite rom for refleksjon og ettertanke. Noen velger å plassere verdier og tvil på hyllen og utfører instrumentelt og lojalt det daglige håndverk. Andre tenker at det viktigste er å holde seg innenfor lover og forskrifter og tilfredsstille tilsynsmyndighetenes forsvarlighetsnorm.

\section{Oppsummering}

Det må bygges bro mellom de etiske utfordringene i den praktiske legegjerning og de verdier som er overlevert oss gjennom kultur og tro. Slik kan legen ivareta egen integritet og verne pasienten mot overgrep. Sentrale kristne verdier som er blitt prøvd gjennom en lang historie, gir grunnlag for å møte fremtidens utfordringer. Bevisstgjøring gjennom forankring og aktualisering er nødvendig for at verdier skal bli noe mer enn bare honnørord.

\section{Stig Heskestad}

stig.heskestad@lyse.net

Jæren distriktspsykiatriske senter

Bryne

\section{Finn Egil Tønnessen}

Det humanistiske fakultet

Universitetet i Stavanger

Stig Heskestad (f.1950) er spesialist i psykiatri, sjeflege ved Jæren distrikspsykiatriske senter NKS.

Forfatter har fylt ur ICMJE-skjemaet og oppgir ingen interessekonflikter.

Finn Egil Tønnessen (f. 1952) dr.philos. i psykologi, mag.art. i filosofi og cand.theol. Han er professor ved Universitetet i Stavanger. Forfatter har fylt ur ICMJE-skjemaet og oppgir ingen interessekonflikter.

\section{Litteratur}

1. Copleston FC. A history of philosophy. Bd.l 7. Part II. New York: Image Books, 1963.

2. Bibelen. Oslo: Bibelselskapet, 2011.

3. Wyatt J. Matters of life \& death. Human dilemmas in the light of the Christian faith. London: Inter Varsity Press, 2009.

4. Vetlesen AJ. Empati under press. Sykepleien 2010 98, nr. 3: 60-3.

5. Eriksen TB. Helse i hver dråpe. Innspill om etikk, kunnskap og omsorg. Oslo: Universitetsforlaget, 1995

6. Fugelli P. Brev fra den andre siden. Tidsskr Nor Lægeforen 1998; 118: 3994-5.

Mottatt 4.10. 2011, første revisjon innsendt 3.1. 2012, godkjent 16.2. 2012. Medisinsk redaktør Petter Gjersvik. 